\title{
Peran Public Relations dalam Memulihkan Reputasi ( Studi Kasus Manajemen Krisis PT Kereta Commuter Indonesia Pasca Perubahan Sistem E-Ticketing)
}

\author{
Ferlita Lourensia, Yugih Setyanto \\ ferlita.915150100@stu.untar.ac.id,yugihs@fikom.untar.ac.id \\ Fakultas Ilmu Komunikasi Universitas Tarumanagara
}

\begin{abstract}
The role of $P R$ is very closely related to the community, where a PR became the liaison between companies with the public especially when a company is experiencing a crisis. The crisis that occurred in the company can influence the reputation of the company. In this study discusses the role of Public Relations in restoring a reputation when the company underwent a crisis of change E-Ticketing System. The research method used was qualitative case study method by using the technique of collecting data through observation, data online, the study of librarianship and the interview with the Manager of Corporate Communications at PT Indonesia, Commuter Train KRL user community to media covering the events of the crisis that occurred at PT KCI. Results of the study found that Public Relations Train Commuter PT Indonesia was doing its part by being an advisor for the company by providing procurement decisions in the interim, paper tickets, besides that $P R$ has also been instrumental in providing information to the public through the media by holding a press conference. Although the company's crisis Manejement of the operational side is still in the development stage, the reputation of the company in terms of monitoring the media have become positive since PT KCI seeks to do positive activities in restoring the reputation of the company
\end{abstract}

Keywords: communication, the role of $P R$, crisis management, reputation

\begin{abstract}
Abstrak
Peran PR sangat erat hubungannya dengan masyarakat, dimana seorang PR menjadi penghubung antara perusahaan dengan masyarakat terutama ketika sebuah perusahaan mengalami sebuah krisis. Krisis yang terjadi dalam perusahaan dapat mempengaruhi reputasi perusahaan. Dalam penelitian ini membahas tentang peran Public Relations dalam memulihkan reputasi ketika perusahaan mengalami sebuah krisis yaitu perubahan sistem $E$ Ticketing. Metode penelitian yang digunakan adalah metode studi kasus kualitatif dengan menggunakan teknik pengumpulan data melalui observasi, data online, studi kepustakaan dan wawancara dengan Manajer Corporate Communications PT Kereta Commuter Indonesia, komunitas pengguna KRL hingga media yang meliput peristiwa krisis yang terjadi di PT KCI. Hasil penelitian yang ditemukan bahwa Public Relations PT Kereta Commuter Indonesia telah melakukan perannya dengan menjadi penasihat bagi perusahaan dengan memberikan keputusan pengadaan tiket kertas sementara, selain itu PR juga telah berperan dalam memberikan informasi kepada publik lewat media dengan mengadakan konferensi pers.Walaupun Manejemen krisis perusahaan dari sisi operasional masih dalam tahap pengembangan, reputasi perusahaan dalam hal monitoring media sudah menjadi positif karena PT KCI berupaya melakukan kegiatan positif dalam memulihkan reputasi perusahaan.
\end{abstract}

Kata Kunci : Komunikasi, Peran PR, Manajemen Krisis, Reputasi 


\section{Pendahuluan}

PT Kereta Commuter Indonesia ( PT KCI ) mengalami sebuah krisis yang diakibatkan oleh perubahan sistem E- Ticketing yang menyebabkan terganggunya jalur masuk tap in dan tap out di semua stasiun yang ada dalam lima rute utama yaitu Jakarta, Bogor, Depok, Tanggerang, Bekasi, dan sekitarnya. Hal ini tentunya membuat kualitas pelayanan dimata masyarakat terlebih pengguna jasa komuter menurun, dan tentunya membuat reputasi dari perusahaan PT KCI pun ikut menurun. Praktisi PR PT KCI harus mampu mengambil langkah untuk memulihkan reputasi perusahaan PT KCI. Mengingat PT KCI sebelumnya telah meraih penghargaan di bidang kehumasan sebagai Best Communicators 2017 kategori CEO Swasta Nasional Non TBK . http://www.krl.co.id/pt-kcj-raih-penghargaan-di-bidangkehumasan/ (diakses pada tanggal 9 September 2018 pukul 20.00 WIB )

Bagaimanapun sarana transportasi kereta komuter merupakan transportasi yang banyak diminati oleh masyarakat Indonesia dari berbagai kalangan, mengingat tarif yang cukup terjangkau dan kecepatan perjalanan menjadi pertimbangan para pengguna komuter untuk kebutuhan dalam menjalankan aktivitas sehari-hari. Selain itu PT KCI merupakan perusahaan yang tidak memiliki pesaing dalam transportasi kereta rel listrik ( KRL).

Oleh karena itu peran PR PT KCI sangat berpengaruh dalam menangani krisis yang disebabkan oleh perubahan sistem kartu multi trip KRL. Selain itu tugas PR adalah mengklarifikasi pemberitaan di media yang telah menyudutkan perusahaan PT KCI. Hal ini bertujuan agar pihak pengguna komuter dan PT KCI sama - sama tidak merasa dirugikan, karena dengan perubahan sistem E-Ticketing membuat para pengguna komuter merasa tidak nyaman terlebih dengan diadakannya karcis kertas sementara membuat perjalanan menggunakan kereta komuter menjadi tidak efektif, dan hal ini membuat jalur masuk dan keluar stasiun menjadi tidak kondusif sehingga banyak pengguna komuter secara sengaja menerobos pintu masuk dan keluar di stasiun asal dan stasiun tujuannya.

Dalam penelitian ini penulis menggunakan teori Komunikasi adalah upaya untuk mencapai kebersamaan. Jika pesan yang disampaikan berjalan dengan lancar maka makna dari komunikator itu dapat diterima oleh komunikan ( Ngalimun, 2017 )

Selain itu ada teori Public Relations, ada empat peran Public Relations yaitu 1) Expert Preciber Communication, PR memiliki peran menjadi ahli dan penasihat bagi pimpinan organisasi dan perusahaan, peran sebagai penasihat meliputi memberikan masukan dan pertimbangan terkait pembuatan keputusan. 2) Problem Solving Process Facilitator, PR berperan sebagai fasilitator ketika perusahaan atau organisasi menyelesaikan suatu masalah. PR dapat menjadi leader dalam menangani krisis yang sedang terjadi 3) Communicator Facilitator, PR memiliki peran menjadi jembatan komunikasi antara organisasi, baik internal maupun eksternal, PR harus mampu sebagai penengah bila terjadi kesalahan persepsi dan 4) Technician Communicator, PR dianggap sebagai pelaksana teknis komunikasi yang menyediakan layanan di bidang teknis. PR dituntut dalam memahami dan menguasai alat komunikasi ( Rosady Ruslan, 2010 ) .

Adapun teori Krisis yaitu perostiwa bersiat spesifik, tidak diharapkan, dapat terjadi setiap saat dan merupakan rangkaian beberapa peristiwa, menimbulkan ketidakpastian dan dapat mengancam tujuan organisasi (Kriyantono,2015). 
Teori lain yang penulis pakai adalah manajemen krisis yang menyebutkan bahwa manajemen krisis adalah upaya dalam mengatasi sebuah krisis yang pada dasarnya merupakan proses bertahap (Kriyantono , 2015).

Dan yang terakhir teori Reputasi yang mengartikan sebagai tujuan utama yang hendak dicapai dalam sebuah perusahaan. Reputasi tidak bisa dilihat, tetapi bisa dirasakan dari penerimaan dan tanggapan publik (Rosady Ruslan, 2010).

\section{Metode Penelitian}

Jenis data yang didapatkan oleh penulis dalam penelitian merupakan jenis studi kasus . Penelitian studi kasus adalah suatu penelitian kualitatif yang berusaha menemukan makna, menyelidiki proses, dan memperoleh pengertian dan pemahaman yang mendalam dari individu, kelompok, atau situasi (Emzir 2012 ). Pada penelitian yang penulis lakukan studi kasus yang diteliti adalah studi kasus tentang peran PR dalam memulihkan reputasi setelah krisis dan mempelajari manajemen krisis dalam perusahaan PT Kereta Commuter Indonesia, data yang diperoleh penulis melalui beberpa proses, yaitu wawancara, observasi, data online dan studi kepustakaan. Dalam penelitian ini subjek penelitian adalah Manajer CorCom PT KCI, Admin "Commuters_UNJ", wartawan Harian Nasional dan pengamat Manajemen Krisis. Sedangkan objek yang penulis teliti adalah krisis yang terjadi akibat perubahan sistem E-Ticketing dan bagaimana langkah Public Relations dalam menghadapi krisis tersebut.

\section{Hasil Temuan dan Diskusi}

Krisis yang dialami oleh PT Kereta Commuter Indonesia terjadi mulai hari Sabtu 21 Juli 2018, krisis ini terjadi karena adanya perubahan sistem yang bertujuan untuk mengembangkan sistem E- Ticketing. Perubahan sistem ini membuat para pengguna Commuterline dihimbau untuk antri dalam melakukan tap in dan tap out pada gate yang terdapat di setiap stasiun, antrian panjang ini juga disebabkan oleh sedikitnya gate yang befungsi untuk melakukan proses masuk dan keluar di Stasiun.

Analisis dampak dari perubahan sistem E-Ticketing: Ketika terjadi perubahan sistem E-Ticketing berdampak pada penumpang KRL yang harus mengantri panjang ketika ingin masuk dan keluar stasiun, berikut berita yang penulis ambil dari Kompas.com

Gambar 1 Berita Tentang Dampak Perubahan Sistem E-Ticketing

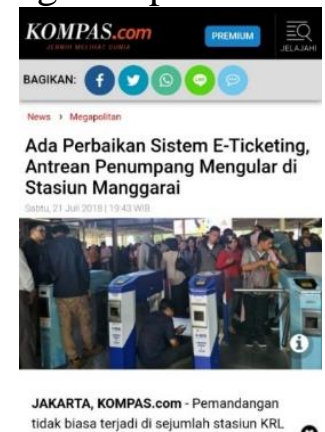

Sumber : https://megapolitan.kompas.com/read/2018/07/21/19432601/adaperbaikan-sistem-e-ticketing-antrean-penumpang-mengular-di-stasiun 
Dampak dari perubahan sistem E-Ticketing sangat dirasakan oleh para pengguna KRL yang harus antri panjang, hal ini disebabkan oleh sebagian gate yang ada di stasiun tidak dapat dioperasikan. Banyak penumpang yang mengeluhkan kejadian ini, karena perubahan sistem ini sangat mengganggu aktivitas penumpang KRL. Adapun permohonan maaf PT KCI yang diwakilkan oleh VP CorCom, Eva Chairunisa tentang pembaharuan dan pemeliharaan sistem yang menyebabkan antrian panjang pada loket dan gate elektronik masuk dan keluar. Selain permohonan maaf dari VP CorCom adapun penjelasan dari petugas Stasiun tujuan dari perubahan sistem ini yaitu menghilangkan kartu KMT yang berseri 1001 karena kartu baru akan menggunakan cip dengan kualitas yang lebih baik.

Definisi Krisis Perubahan Sitem E-Ticketing Pada PT Kereta Commuter Indonesia, dari hasil wawancara penulis menyimpulkan bahwa perubahan sistem ETicketing yang dilakukan oleh PT Kereta Commuter Indonesia bertujuan untuk meningkatkan keamanan dan integrasi antar moda, namun karena kurangnya mitigasi waktu dan sosialisasi tentang perubahan sistem ini, maka waktu perubahan sistem ini tidak sesuai dengan target yang ditentukan perusahaan, sebelumnya perusahaan telah menargetkan proses upgrade selama tiga hari di hari weekend sudah selesai dan pada hari Senin 23 Juni semua dapat berjalan dengan normal, namun kenyataannya sebaliknya hal ini membuat antrian yang panjang dan membuat pengguna KRL merasa dirugikan terutama dari segi waktu karena yang biasanya tidak harus antri membeli tiket, penumpang diharuskan membeli tiket karena diberlakukannya tiket kertas sebagai kebijakan yang dikeluarkan perusahaan ketika sistem tidak berjalan .Hal ini sesuai dengan pengertian krisis mendefinisikan krisis adalah peristiwa yang bersifat spesifik, tidak diharapkan, dapat terjadi setiap saat dan merupakan rangkian dari beberapa peristiwa menimbulkan ketidakpastian dan dapat mengancam tujuan organisasi ( Kriyantono 2015).

Krisis memiliki karakteristik, karakterisitk krisis terdiri dari enam karakterisitik diantaranya adalah perisitwa yang spesifik, krisis tidak dapat dihindari, krisis menciptakan ketidakpastian, menimbukan kepanikan dan keterkejutan, menimbulkan dampak positif atau negatif bagi operasional organisasi dan berpotensi menimbulkan konflik (Kriyantono 2015). Berdasarkan wawancara dengan Manager Corporate Communications Adli Hakim Nasution, krisis perubahan sistem E-Ticketing masuk dalam semua karakterisitk dimana krisis perubahan sistem merupakan peristiwa yang spesifik karena sumber krisis tersebut muncul karena kurangnya mitigasi waktu dan sosialisasi yang dilakukan perusahaan kepada pengguna KRL, krisis tidak dapat dihindari karena krisis yang terjadi di PT KCI merupakan peristiwa yang tidak diharapkan dan krisis ini menjadi perbincangan para publik terutama pengguna KRL yang merasa dirugikan dalam hal waktu, krisis menciptakan ketidakpastian informasi, dalam hal ini menimbulkan isu yang mengaitkan krisis yang terjadi dengan isu yang tidak sebenarnya terjadi, seperti yang diungkapkan oleh Manager CorCom

"orang bertanya -tanya apa upaya KCI ini untuk supaya orang tidak pake kartu bank pake KMT aja itu juga harus isu yang kita clear kan waktu itu, dari waktu itu isu yang menimpa perusahaan terus lain - lain ya isunya dari isu pecah kongsi sama Telkom yang sama- sama perusahaan BUMN, itu masih ada terus tuh sampe sebulan sejak hmm kejadian upgrade system" (Hasil wawancara dengan Manager CorCom )

Krisis menimbulkan kepanikan dan keterkejutan, hal ini tentunya membuat para pengguna KRL menjadi panik, karena merasakan dampak dari perubahan sistem tersebut dengan mengantri panjang untuk membeli tiket kertas. Krisis menimbulkan dampak positif dan negatif, dalam hal ini perusahaan PT KCI tentunya 
menerima dampak negatif dari peristiwa tersebeut karena banyak yang mempertanyakan kredibilitas perusahaan sebagai penyedia jasa kereta Commuterline, krisis berpotensi menimbulkan konflik, krisis perubahan sistem ini tentunya menimbulkan sebuah konflik karena adanya ketidaksesuaian antara harapan PT KCI dengan apa yang terjadi dalam perusahaan atau organisasi. Konflik juga muncul karena banyak pemberitaan negatif oleh media online sehingga menarik perhatian publik. Oleh karena itu hal krisis yang terjadi di PT Kereta Commuter Indonesia sesuai dengan karakteristik krisis yang terdapat dalam buku Kriyantono (2015)

Public Relations juga memiliki peran dalam suatu perusahaan,peranan praktisi PR menurut Dozier and Broom ( dalam Rosady Ruslan , 2010:20) dibedakan menjadi dua peranan, yaitu peranan manajerial ( Communication Manager Role ) dan peranan teknis ( Communication Technician Role ). Peranan manajerial dapat diuraikan menjadi tiga bagian, yakni expert preciber facilitator, problem solving process facilitator dan communication facilitator .

\section{Expert Preciber Communication}

Dalam hal ini PR berberapan sebagai penasihat bagi pimpinan perusahaan, berupa masukan atau pertimbangan dalam membuat keputusan seperti memberi himbauan agar informasi tidak ada yang ditutup-tutupi, perusahaan tidak boleh memberikan pernyataan bohong atau dengan kata lain harus memberikan informasi yang jujur karena public memiliki hak untuk mengetahui fakta yang sebenarnya ( Carlina \& Paramita , 2017 ) dan memberi masukan untuk mengeluarkan tiket kertas dan melakukan konferensi pers . Sesuai dengan teori diatas, peran PR dalam PT Kereta Commuter Indonesia sudah berperan sebagai penasihat kepada para pimpinan manajemen untuk memberikan informasi sesuai dengan keadaan, dan memberikan masukan berupa pertimbangan dalam menjual tiket kertas.

2. Problem Solving Process Facilitator

Peran PR sangat penting sebagai fasilitator ketika PT KCI menyelesaikan sebuah krisis, peran dalam hal ini memberikan informasi yang jelas tentang perkembangan atas penanganan krisis akibat perubahan sistem E-Ticketing, dalam hal ini PR harus tanggap dalam menyelesaikan masalah tersebut. Sesuai dengan hasil wawancara diatas dapat disimpulkan bahwa Public Relations PT Kereta Commuter Indonesia sudah menjalankan perannya sebagai leader dalam menangani krisis yang sedang terjadi dengan memberikan ruang pada pimpinan untuk mempelajari dan mengambil keputusan untuk masalah krisis tersebut.

\section{Communicator Facilitator}

Peran PR sebagai jembatan komunikasi antara perusahaan dengan media ataupun pengguna KRL. Dalam hal ini seorang PR harus menjadi penengah antara perusahaan dengan media dengan memberikan informasi sesuai dengan hasil wawancara penulis dengan media dari Harian Nasional, Dian pada tanggal 21 November 2018 mengungkapkan bahwa PT KCI sudah memberikan informasi kepada pihak media, tidak hanya ketika ada krisis dalam perusahaan, PT KCI pun sering mengundang media dari berbagai acara, seperti pernyataan yang diberikan oleh Dian

Berbeda dari sisi pengguna, Hamas sebagai admin dari komunitas "Commuters_UNJ" ketika ditanya soal informasi tentang perubahan sistem ETicketing mengungkapkan bahwa komunitas tersebut tidak secara langsung mendapatkan informasi dari PR PT Kereta Commuter Indonesia, 
Dapat disimpulkan bahwa peran PR memiliki jembatan komunikasi yang baik antara perusahaan dengan media dalam memberikan informasi tentang krisis yang sedang terjadi, namun berbeda halnya dengan komunitas pengguna KRL yang merupakan perwakilan dari para pengguna KRL, peran PR dalam memberikan informasi belum cukup karena informasi yang didapat oleh komunitas "Commuters_UNJ" berasal dari komunitas lain, bukan dari PT Kereta Commuter Indonesiasecara langsung.

\section{Technician Communicator}

Peran PR juga dapat dikatakan sebagai pelaksana teknis komunikasi yang menyediakan layanan teknis berupa layanan dalam membuka akses informasi tentang krisis yang sedang terjadi. Hal ini dapat disimpulkan bahwa akses yang diberikan kepada media lebih terbuka dibanding akses informasi kepada publik, hal ini disebabkan karena media sangat mempengaruhi reputasi perusahaan, terlebih dari segi pemberitaan, dengan dibukanya informasi yang luas kepada media dibandingkan kepada publik, maka pemberitaan yang diberitakan media dapat membantu perusahaan dalam memberikan informasi kepada pengguna KRL dengan bahasa yang lebih dimengerti oleh publik, dan hal ini dapat membuat pemberitaan media yang negatif dapat berubah menjadi positif, karena PR dengan terbuka membuka akses kepada media.

\section{Simpulan}

Public Relations PT Kereta Commuter Indonesia telah melakukan perannya dengan baik dalam memulihkan reputasi akibat krisis yang disebabkan oleh perubaan sistem E-Ticketing, meskipun krisis yang dihadapi menimbulkan kepanikan, dan konflik berupa isu baru dalam perusahaan PR PT Kereta Commuter Indonesia harus cepat memberikan respon dalam memberikan konfirmasi yang akurat pada media, sera dalam mengambil keputusan PR harus bekerja dengan cepat dalam meanggulangi krisis tersebut (Anom \& Handayani ,2010), selain itu PR PT Kereta Commuter Indonesia juga mampu memberikan kebijakan dalam mengatasi krisis perubahan sistem E- Ticketing, selain itu PR juga mampu menjadi leader dan jembatan antara perusahaan dengan publik dalam menangani krisis. Walaupun manajemen krisis operasional perusahaan masih dalam proses pengembangan, namun dengan kegiatan positif yang dilakukan oleh Public Relations mampu merubah reputasi perusahaan dalam hal pemberitaan menjadi positif kembali.

\section{Ucapan Terima Kasih}

Penulis ingin mengucapkan terimakasih kepada PT Kereta Commuter Indonesia yang telah menyediakan waktu dan tempat untuk penulis dalam melakukan penelitian. Selain itu penulis juga berterimakasih kepada narasumber yang telah bersedia untuk wawancara dengan penulis yaitu Adli Hakim Nasution, Manajer CorCom PT KCI, Hamas admin dari komunitas "Commuters_UNJ", Dian sebagai wartawan dari Harian Nasional dan Anto Sudarto sebagai pengamat dari Manajemen Krisis. Dan tak lupa rasa terimakasih yang sangat terdalam untuk Bapak Yugih Setyanto,S.Sos.,M.Si sebagai pembimbing yang membimbing peneliti dari awal hingga akhir penelitian, serta peneliti juga ingin berterimakasih kepada teman dan keluarga atas bantuan yang diberikan. 
Ferlita Lourensia,Yugih Setyanto: Peran Public Relations Dalam Memulihkan Reputasi ( Studi Kasus Manajemen Krisis PT Kereta Commuter Indonesia Pasca Perubahan Sistem E-Ticketing)

\section{Daftar Pustaka}

Emzir. (2012). Analisis Data:Metodologi Penelitian Kualitatif. Jakarta:PT RajaGarfindo Persada

Kriyantono, Rachmat. (2015). Public Relations, Issue \& Crisis Management. Jakarta: Prenadamedia Group

Ruslan, Rosady. (2010). Manajemen Public Relations dan Media Komunikasi.Jakarta:PT RajaGrafindo Persada

Anom \& Handayani.(2010). Peran PR Menerapkan Manajemen Krisis Dalam Memulihkan Citra PT Garuda Indonesia Pasca Kecelakaan Pesawat Boeing G.737/400 di Yogyakarta”, Jurnal Ilmu Komunikasi Universitas Esa Unggul. http://fikom.weblog.esaunggul.ac.id/tag/jurnal-komunikologi-vol-7-no-1maret-2010/ diakses pada 17 September 2018 pukul 14.13

Carlina, G., \& Paramita, S. (2017). PR Crisis Melalui Media Sosial. Jurnal Komunikasi, 9(1), 81-86. Retrieved from https://journal.untar.ac.id/index.php/komunikasi/article/view/211 diakses pada 17 September 2018 pukul 13.24

"Ada Perbaikan Sistem E-Ticketing, Antrean Penumpang Mengular di Stasiun Manggarai"'(2018)

https://megapolitan.kompas.com/read/2018/07/21/19432601/ada-perbaikansistem-e-ticketing-antrean-penumpang-mengular-di-stasiun (diakses pada tanggal 4 Desember 2018) 